\title{
The effects of mangosteen peel (Garcinia mangostana L.) and Turmeric (Curcuma domestica Val) flour dietary supplementation on the growth performance, lipid profile, and abdominal fat content in Cihateup ducks
}

\author{
Andri Kusmayadi ${ }^{1}$, Kamiel Roesman Bachtiar ${ }^{2}$ and Caribu Hadi Prayitno ${ }^{3}$
}

1. Department of Animal Science, Faculty of Agriculture, Universitas Perjuangan, Tasikmalaya 46115, West Java, Indonesia; 2. Department of Pharmacy, Faculty of Health Science, Universitas Perjuangan, Tasikmalaya 46115, West Java, Indonesia; 3. Department of Feed Science, Faculty of Animal Science, Universitas Jenderal Soedirman, Purwokerto 53123, Central Java, Indonesia.

Corresponding author: Andri Kusmayadi, e-mail: andrikusmayadi1@gmail.com Co-authors: CHP: caribuunsoed@gmail.com, KRB: kharoes234@gmail.com

Received: 01-10-2018, Accepted: 05-02-2019, Published online: 15-03-2019

doi: 10.14202/vetworld.2019.402-408 How to cite this article: Kusmayadi A, Bachtiar KR, Prayitno CH (2019) The effects of mangosteen peel (Garcinia mangostana L.) and Turmeric (Curcuma domestica Val) flour dietary supplementation on the growth performance, lipid profile and abdominal fat content in Cihateup ducks, Veterinary World, 12(3): $402-408$.

\begin{abstract}
Background: Bioactive compounds in mangosteen peel and turmeric have been shown to possess antioxidant and hypolipidemic properties.
\end{abstract} Aim: This study aimed to examine the effect of mangosteen peel flour (MF) and turmeric flour (TF) dietary supplementation
on the performance, lipid profile, and abdominal fat content of Cihateup ducks.

\begin{abstract}
Materials and Methods: The study was conducted for 56 days (8 weeks) using 84-day-old male Cihateup ducks that were allocated into seven treatments with three replications and each containing four ducks as subreplicates. The seven groups were positive control, containing $100 \%$ of basal ration/BR $+50 \mathrm{ppm}$ bacitracin $\left(\mathrm{R}_{0}\right), \mathrm{BR}+2 \% \mathrm{MF}\left(\mathrm{R}_{1}\right)$, $\mathrm{BR}+$ $1.5 \% \mathrm{MF}+0.5 \% \mathrm{TF}\left(\mathrm{R}_{2}\right), \mathrm{BR}+1 \% \mathrm{MF}+1 \% \mathrm{TF}\left(\mathrm{R}_{3}\right), \mathrm{BR}+0.5 \% \mathrm{MF}+1.5 \% \mathrm{TF}\left(\mathrm{R}_{4}\right), \mathrm{BR}+2 \% \mathrm{TF}\left(\mathrm{R}_{5}\right)$, and $\mathrm{BR}$ only as negative control $\left(\mathrm{R}_{6}\right)$. The data of each variable were analyzed using a completely randomized design (one way). Significant differences $(\mathrm{p}<0.05)$ were determined with Duncan test.
\end{abstract}

Results: The results indicated that the addition of MF and TF significantly affected $(\mathrm{p}<0.05)$ body weight, weight gain, mortality rate, low-density lipoprotein, high-density lipoprotein, and abdominal fat levels. At the same time, MF and TF significantly influenced $(\mathrm{p}<0.01)$ total cholesterol and triglyceride concentration. Non-significant differences $(p>0.05)$ in feed intake and feed conversion of Cihateup ducks were observed.

Conclusion: The combination of $\mathrm{MF}$ and $\mathrm{TF}$ at a balanced ratio $\left(\mathrm{R}_{3}\right)$ can be used as an alternative feed additive to improve performance, lipid profile, and abdominal fat of Cihateup ducks.

Keywords: Cihateup duck, lipid profile, mangosteen peel flour, performance, turmeric flour.

\section{Introduction}

Cihateup duck is local poultry species from Tasikmalaya, West Java, Indonesia, which serves both as meat and egg producer. Cihateup duck has slower growth rates, worse feed conversion rate, and carcass with higher fat content [1] and high blood cholesterol levels [2] compared to broilers. Therefore, the current research is focused on feed additives that can improve growth performance with a concomitant reduction of fat content in duck carcass. In order to overcome this problem, farmers usually use synthetic antibiotics. The application of synthetic antibiotics is very effective in giving a boost to growth but has a negative impact on consumer's health such as resistance to certain antibiotics, carcinogenic responses (cancer risk),

Copyright: Kusmayadi, et al. Open Access. This article is distributed under the terms of the Creative Commons Attribution 4.0 International License (http://creativecommons.org/licenses/ by/4.0/), which permits unrestricted use, distribution, and reproduction in any medium, provided you give appropriate credit to the original author(s) and the source, provide a link to the Creative Commons license, and indicate if changes were made. The Creative Commons Public Domain Dedication waiver (http:// creativecommons.org/publicdomain/zero/1.0/) applies to the data made available in this article, unless otherwise stated. and residues in the derived products. The effects of synthetic antibiotic residues in food can cause transfer of resistant bacteria to the human organism, immunological effects, carcinogenic, mutagenic, hepatotoxic, reproductive disorders, and allergies [3].

The herbal feed additives could serve as an alternative to antibiotics because they have many benefits and are natural, safe, and environmentally friendly [4]. Turmeric is an herb that has the potential to improve livestock growth while reducing fat level in carcass. Broiler chicks fed turmeric flour (TF) had increased weight gain, improved energy efficiency, and feed conversion ratio (FCR) [5,6]. In addition, turmeric also has a good impact on improving the blood lipid profile of poultry [7]. Curcuminoid substances possess antibacterial properties and can stimulate the gallbladder wall to secrete bile so that it can facilitate fat metabolism $[8,9]$. At the same time, mangosteen peel contains xanthones exerting hypolipidemic [10] and hypocholesterolemic [11] activities. This decrease in blood cholesterol levels is caused by inhibition of cholesterol synthesis in the body [11]. In addition, mangosteen peel contains high levels of antioxidants [12] 
and can reduce the stress level of ducks. Apart from xanthone, mangosteen peel contains $\alpha$-mangosteen, a pigment that can improve secretion of pancreatic lipase and $\alpha$-amylase; enzymes that play a significant role in antiobesity mechanism [10].

Apart from turmeric, mangosteen peel could serve as a supplement of duck diets. The use of these agents (both turmeric and mangosteen peel) has never been tested in Cihateup ducks although both possess properties that support and complement each other. Therefore, this study aimed to examine the effect of mangosteen peel flour (MF) and TF dietary supplementation on the performance, lipid profile, and abdominal fat content of Cihateup ducks.

\section{Materials and Methods}

\section{Ethical approval}

The use of material (ducks) in this study has been approved by the Animal Ethics Committee for Using Animal and Scientific Procedures in Faculty of Animal Science, Universitas Padjadjaran, Indonesia.

\section{Animal and treatments}

Selection was done by using a simple method involving several five senses to choose male ducks only from hatchery (recommended by duck breeder expert). Male ducks can be selected easily using (1) the sense of sight to observe male genitals which are characterized by a slight bulge, the color of the fur that looks more dark brown and body posture that tends to be larger than the female duck; (2) the sense of hearing to observe the sound of male ducks marked with a voice that is more hoarse and less loud. The 84 male Cihateup ducks of day old were assigned into seven treatment groups, namely positive control containing $100 \%$ basal ration/BR $+50 \mathrm{ppm}$ bacitracin $\left(\mathrm{R}_{0}\right), \mathrm{BR}+2 \% \mathrm{MF}\left(\mathrm{R}_{1}\right)$,

Table-1: Diet composition and analysis.

\begin{tabular}{lcc}
\hline Feed composition & \multicolumn{2}{c}{ Period (\%) } \\
\cline { 2 - 3 } & $\begin{array}{c}\text { Starter } \\
\text { (0-3 weeks) }\end{array}$ & $\begin{array}{c}\text { Grower } \\
\text { (4-8 weeks) }\end{array}$ \\
\hline Corn & 29.80 & 26.00 \\
Soybean meal & 8.54 & 9.00 \\
Bran & 33.50 & 33.00 \\
Fish meal & 8.54 & 9.00 \\
Basal ration & 18.40 & 21.27 \\
Essential oil & 0.50 & 0.70 \\
Salt & 0.15 & 0.15 \\
Dicalcium phosphate & 0.50 & 0.50 \\
Premix & 0.07 & 0.07 \\
Methionine & 0.03 & 0.08 \\
Nutrient (\%) & & \\
Water content & 11.00 & 12.00 \\
Protein & 18.70 & 15.40 \\
Crude fat & 6.88 & 5.88 \\
Crude fiber & 5.15 & 5.45 \\
Ash & 6.50 & 6.50 \\
Ca & 0.72 & 0.72 \\
P & 0.42 & 0.36 \\
Methionine+Cystine & 0.69 & 0.57 \\
Lysine & 1.10 & 0.90 \\
Energy (Kcal EM/kg) & 2900 & 2900 \\
\hline
\end{tabular}

$\mathrm{BR}+1.5 \% \mathrm{MF}+0.5 \% \mathrm{TF}\left(\mathrm{R}_{2}\right), \mathrm{BR}+1 \% \mathrm{MF}+1 \% \mathrm{TF}$ $\left(\mathrm{R}_{3}\right), \mathrm{BR}+0.5 \% \mathrm{MF}+1.5 \% \mathrm{TF}\left(\mathrm{R}_{4}\right), \mathrm{BR}+2 \% \mathrm{TF}\left(\mathrm{R}_{5}\right)$, and $B R$ only as negative control $\left(\mathrm{R}_{6}\right)$. The dietary supplementation with MF and TF started from the $2^{\text {nd }}$ week until the end of the maintenance period ( 8 weeks). Drinking water was provided ad libitum. The diet composition and analysis are presented in Table-1.

\section{Performance measurements}

Cihateup ducks were weighed every week to measure weekly (UN) weight gain. Feed intake was daily recorded. Feed remnants were measured for the estimation of intake. Feed conversion was calculated by dividing feed intake with body weight $(\mathrm{BW})$ gain. Mortality rate was also measured by counting the number of died ducks during the experimental period.

\section{Lipid profile and abdominal fat level determination}

Blood samples of Cihateup duck taken through the brachial vein and analyzed to determine cholesterol, triglycerides, high-density lipoprotein (HDL), and low-density lipoprotein (LDL) levels. Blood samples of Cihateup duck were collected through the brachial vein. Blood was collected in ethylenediaminetetraacetic acid tubes. Then, it was stored in a cooler box. Then, it was stored in a cooler box and was centrifuged at $4000 \mathrm{rpm}$ for $10 \mathrm{~min}$ to obtain blood plasma. After this procedure, blood plasma was removed in the Eppendorf tube and put into the freezer before analyses. Cholesterol levels were determined by the CHOD-PAP enzymatic colorimetric method, triglyceride levels were determined with the GPO-PAP method, and HDL analysis was determined using the enzymatic colorimetric method after precipitation of $\beta$-lipoprotein with phosphotungstate and magnesium chloride. LDL levels were obtained using formula LDL $=$ Total cholesterol - HDL - 1/5 Triglycerides. Abdominal fat levels were calculated by comparing the weight of abdominal fat and the live weight of ducks.

\section{Statistical analysis}

The data obtained were processed using a completely randomized design (one way). Significant differences $(p<0.01$ or $p<0.05)$ were determined with Duncan test.

\section{Results and Discussion}

\section{BW}

Based on the data presented in Table-2, dietary supplementation with MF and TF significantly increased $(p<0.05)$ BW of Cihateup ducks compared to negative control group. The combination of MF and TF $\left(\mathrm{R}_{3} ; 1 \%\right.$ and $1 \%$ and $\mathrm{R}_{4} ; 0.5 \%$ and $1.5 \%$, respectively) showed the best results compared to controls and other treatments. The results of the present study are in accordance with that of Ürüşan and Bölükbaş1 [13] who report that the addition of TF at the level of $10 \mathrm{~g} / \mathrm{kg}$ $(1 \%)$ in the diet has a significant effect $(p<0.05)$ on the broiler BW. The addition of MF combined with ginger at the level of $1 \%$ significantly influences $(p<0.05)$ the BW of broilers that are reared under heat stress [11]. 
Similar results are reported by Palapol et al. [14] who found that the use of mangosteen peel improves the performance and BWs of broilers.

This study confirms that the consumption of curcumin in turmeric and xanthone in mangosteen peel by the livestock results in an increase of the BW in Cihateup ducks. The addition of these herbal ingredients in a balanced ratio has a greater impact than the single incorporation of them or the other combinations of herbs. Turmeric and mangosteen peel play a significant role in increasing the effectiveness of the digestive system by balancing the intestinal microflora population through their antimicrobial properties [15] and as a result, an increased BW is observed.

\section{Weight gain}

The data in Table-2 show that supplementation of MF and TF significantly affect $(p<0.05)$ weight gain of Cihateup ducks. $R_{3}$ and $R_{5}$ groups had the greatest values among the experimental groups. This result is consistent with the findings of Mondal et al. [16] who state that the addition of TF in broiler feed has a significant effect $(p<0.05)$ on the weight gain, feed conversion, and decreased the levels of abdominal fat $(p<0.01)$. This happens because the antioxidant activity of mangosteen peel and turmeric is optimal at the level of $1 \%$ so that it can stimulate the synthesis of enzymes and proteins in the digestive system of poultry, especially the secretion of endogenous digestive enzymes [17]. In addition, bioactive compounds in these herbal ingredients play a role in reducing intestinal viscosity so that they are positively correlated with nutrient absorption and ultimately have a significant effect on weight gain.

In another study, the addition of TF and MF did not have a significant effect on weight gain [18]. They reported that turmeric dietary supplementation at various levels $(0.25,0.5,0.75$, and $1 \%)$ had no significant effects on the weight gain of broilers. Ratika et al. [19] further reported that the addition of $0.5 \%$ of turmeric in the diet did not have a significant effect on broiler growth performance. On the other hand, TF at the level of $2 \%$ affected weight gain in rabbits [20].

\section{Feed intake}

The data in Table- 2 show that the supplementation of MF and TF does not have a significant effect $(p>0.05)$ on the feed intake of Cihateup duck. These findings are in accordance with the previous studies which state that at the same time, the addition of turmeric at the level of 1.0, 2.0, and 3.0\% has no significant effect on feed intake, egg weight, and chicken egg production level $[21,22]$. The other studies report that the addition of MF to Mojosari ducks at the level of 1.5\% does not affect feed intake, weight gain, and feed conversion [23]. Although not shown in the present study, several bioactive compounds in herbal plants are able to stimulate appetite and increase feed intake and secretion of endogenous digestive enzymes, activate immune responses, antioxidants, and antimicrobials [24].

\section{FCR}

Table-2 shows that MF and TF had no significant effect $(p>0.05)$ on the feed conversion. This is consistent with previous literature by Emadi and Kermanshahi [25] which reports that the addition of turmeric at the level of $2.5,5$, and $7.5 \mathrm{~g} / \mathrm{kg}$ of feed does not affect the BW and feed conversion of broiler chickens. Meanwhile, $5 \mathrm{~g}$ of turmeric per $\mathrm{kg}$ of feed does not affect the BW and feed conversion of broiler chickens although has an impact on the feed consumption and conversion from the starter period to the finisher period [26]. On the other hand, there are studies that show a negative impact of turmeric at the level of $1 \%$ on feed intake, weight gain, and feed conversion [27]. Moreover, Attia [22] reported that the addition of turmeric combined with other herbs at a balanced level $(0.15: 0.15)$ has a significant influence on the feed conversion parameters. In this case, herbal bioactive compounds play a role in regulating the amount of feed intake, affecting the microflora to reduce the activity of pathogenic bacteria in absorbing feed nutrients.

\section{Mortality rate}

The mortality values presented in Table- 2 show that supplementation of MF and TF significantly affected $(p<0.05)$ mortality rate of Cihateup ducks. This study is in accordance with the report from Samarasinghe et al. [21] which states that the use of herbs as feed additives in broiler diets shows a great efficiency as antimicrobial agents, especially against Escherichia coli and coliform bacteria in the duodenum. Ürüşan and Bölükbaş1 [13] also report that $\mathrm{TF}$ at a level of $0.6-1 \%$ could significantly $(\mathrm{p}<0.01)$ reduce $E$. coli counts in jejunum. On the other hand,

Table-2: Average performance of Cihateup ducks given ration contains mangosteen peel flour and turmeric flour of research results.

\begin{tabular}{|c|c|c|c|c|c|}
\hline Treatments & Body weight (g) & $\begin{array}{l}\text { Weight } \\
\text { gain (g) }\end{array}$ & $\begin{array}{c}\text { Feed } \\
\text { intake (g) (ns) }\end{array}$ & $\begin{array}{c}\text { Feed } \\
\text { conversion (ns) }\end{array}$ & Mortality (\%) \\
\hline $\mathrm{R}_{0}$ (Positive control) & $1453.25 \pm 68.13^{b}$ & $923.46 \pm 23.56^{b}$ & $4464.03 \pm 103.24$ & $5.07 \pm 0.56$ & $0.00 \pm 0.00^{a}$ \\
\hline $\mathrm{R}_{1}(2 \% \mathrm{MF})$ & $1457.56 \pm 57.67^{b}$ & $885.34 \pm 41.14^{\mathrm{ab}}$ & $4437.17 \pm 117.65$ & $5.21 \pm 0.87$ & $1.39 \pm 0.20^{\mathrm{b}}$ \\
\hline $\mathrm{R}_{2}(1.5 \% \mathrm{MF}+0.5 \% \mathrm{TF})$ & $1453.56 \pm 39.22^{b}$ & $877.34 \pm 33.87^{a b}$ & $4445.75 \pm 98.26$ & $5.11 \pm 0.45$ & $0.00 \pm 0.00^{a}$ \\
\hline $\mathrm{R}_{3}(1 \% \mathrm{MF}+1 \% \mathrm{TF})$ & $1568.87 \pm 98.76^{c}$ & $985.00 \pm 65.43^{c}$ & $4469.00 \pm 138.27$ & $5.03 \pm 0.23$ & $0.00 \pm 0.00^{a}$ \\
\hline $\mathrm{R}_{4}(0.5 \% \mathrm{MF}+1.5 \% \mathrm{TF})$ & $1534.33 \pm 54.41^{c}$ & $948.46 \pm 57.76^{b}$ & $4427.33 \pm 156.59$ & $5.08 \pm 0.44$ & $0.00 \pm 0.00^{a}$ \\
\hline $\mathrm{R}_{5}(2 \% \mathrm{TF})$ & $1473.44 \pm 35.23^{b}$ & $974.66 \pm 34.28^{c}$ & $4481.67 \pm 115.30$ & $5.12 \pm 0.38$ & $0.00 \pm 0.00^{a}$ \\
\hline $\mathrm{R}_{6}$ (Negative control) & $1293.75 \pm 43.79^{a}$ & $776.49 \pm 36.24^{a}$ & $4334.67 \pm 100.45$ & $5.24 \pm 1.03$ & $2.74 \pm 0.34^{b}$ \\
\hline
\end{tabular}

Description-Superscript different within the same column shows a significant difference, ns=Non significant, $\mathrm{MF}=$ Mangosteen peel flour, $\mathrm{TF}=$ Turmeric flour 
the addition of turmeric at a higher level $(2 \%)$ can increase the amount of lactic acid bacteria which is very useful as a natural probiotic.

The data in Table- 2 prove that all treatments containing turmeric have zero mortality because turmeric could also act as an immunomodulator [28] and improve blood biochemical parameters, livestock health status, and nutrient metabolism in the body [29]. This is also supported by the role of turmeric as an antioxidant compound; cattle that are challenged with aflatoxin B1 are more resistant to stress after turmeric supplementation by reducing the production of free radicals [30]. The increased antioxidant activity is also related to the increased glutathione peroxidase and superoxide dismutase activities as shown in broilers that are kept under stress conditions [31].

\section{Lipid profiles}

\section{Total cholesterol}

The effect of supplementation of the MF and TF on total cholesterol levels is presented in Table-3. The use of mangosteen peel and TF $\left(\mathrm{R}_{1}, \mathrm{R}_{2}\right.$, and $\mathrm{R}_{3}$ groups) has a significant effect $(\mathrm{p}<0.01)$ on total blood cholesterol levels in Cihateup ducks compared to that of $\mathrm{R}_{6}$ group. The combination treatment of MF and $\mathrm{TF}$ at the level of $1.5 \%+0.5 \%$ shows the lower values compared to the other treatments. These results are consistent with a previous study which states that the addition of herbal combination of TF and thyme can reduce the level of total cholesterol, HDL, LDL, and blood triglycerides in broiler chickens [6]. Total cholesterol level can also be decreased by adding a combination of mangosteen peel with ginger [11]. Xanthones have a hypocholesterolemic activity which is able to reduce cholesterol levels [32].

Adiputro et al. [33] reported that the reduction in blood cholesterol levels is observed as a result of the inhibition of cholesterol formation. During the formation of cholesterol, there is a stage of squalene synthesis. At this stage, the formation of the two molecules of farnesyl pyrophosphate and elimination of pyrophosphate radicals occur. The formation of the two molecules of farnesyl pyrophosphate is characterized by the production of two farnesyl pyrophosphate radicals.
This production is inhibited by the antioxidant properties of the ethanolic extract of mangosteen pericarp, thus inhibiting squalene formation. Chomnawang et al. [34] also demonstrated the potential of mangosteen pericarp to inhibit superoxide radicals through the mechanism of the transfer of electrons or hydrogen atoms. Concerning the mechanism of increased cholesterol catabolism, cholesterol is converted into bile salts. The process of conversion of cholesterol into bile salts requires the availability of oxygen, NADPH, and cytochrome $\mathrm{p} 450$. Therefore, the mechanism of cholesterol reduction by mangosteen pericarp in the present study was performed through the inhibition of cholesterol synthesis [33].

\section{Triglyceride}

The data in Table- 3 show that the supplementation with $\mathrm{MF}$ and $\mathrm{TF}$ plays a significant role in reducing blood triglyceride levels $\left(\mathrm{R}_{3}\right.$ and $\mathrm{R}_{4}$ group) $(p<0.01)$. The combination treatment of MF and TF at $\mathrm{R}_{3}$ and $\mathrm{R}_{4}$ shows the best results compared to other treatments. The data are in accordance with a previous study reporting that the combination of turmeric and thyme has a significant effect on decreasing blood triglyceride level due to a reduction in enzyme activity synthesis [6]. The other factors are that curcumin in turmeric possesses hypolipidemic properties that cause not only a decrease of triglycerides but also of total cholesterol, HDL, and LDL [6]. Likewise, another study by Hidanah et al. [11] reports that broiler's blood triglyceride level can be decreased by adding a combination of mangosteen peel with ginger. The combination of mangosteen peel and turmeric has a better effect on decreasing blood triglyceride level than other treatments. The reduction in triglyceride levels in the present study (Table-3) was possibly caused by the increased very LDL (VLDL) and chylomicron catabolism. VLDL is a triglyceride transporter originating in the liver, while chylomicrons are triglyceride transporters from the intestines. VLDL and chylomicron catabolism are affected by lipoprotein lipases that hydrolyze triglycerides into free fatty acids and glycerol [33].

Table-3: Average lipid profiles of Cihateup ducks given ration contain mangosteen peel flour and turmeric flour of research results.

\begin{tabular}{lcccc}
\hline Treatments & \multicolumn{3}{c}{ Lipid profiles } \\
\cline { 2 - 5 } & Total cholesterol* & Triglycerides* & LDL** & HDL** \\
\hline $\mathrm{R}_{0}($ Positive control) & $143.80 \pm 36.34^{\mathrm{b}}$ & $81.80 \pm 4.95^{\mathrm{b}}$ & $47.70 \pm 4.59^{\mathrm{ab}}$ & $62.65 \pm 7.35^{\mathrm{b}}$ \\
$\mathrm{R}_{1}(2 \% \mathrm{MF})$ & $146.50 \pm 4.24^{\mathrm{b}}$ & $96.30 \pm 53.88^{\mathrm{c}}$ & $46.40 \pm 3.61^{\mathrm{ab}}$ & $58.95 \pm 4.95^{\mathrm{ab}}$ \\
$\mathrm{R}_{2}(1.5 \% \mathrm{MF} \pm 0.5 \% \mathrm{TF})$ & $125.45 \pm 5.73^{\mathrm{a}}$ & $93.70 \pm 17.82^{\mathrm{c}}$ & $40.40 \pm 4.38^{\mathrm{a}}$ & $54.50 \pm 1.98^{\mathrm{a}}$ \\
$\mathrm{R}_{3}(1 \% \mathrm{MF} \pm 1 \% \mathrm{TF})$ & $132.75 \pm 20.72^{\mathrm{ab}}$ & $59.65 \pm 11.53^{\mathrm{a}}$ & $44.35 \pm 9.12^{\mathrm{ab}}$ & $56.55 \pm 6.58^{\mathrm{ab}}$ \\
$\mathrm{R}_{4}(0.5 \% \mathrm{MF} \pm 1.5 \% \mathrm{TF})$ & $151.25 \pm 27.22^{\mathrm{bc}}$ & $81.35 \pm 17.18^{\mathrm{b}}$ & $49.65 \pm 10.67^{\mathrm{b}}$ & $65.55 \pm 9.55^{\mathrm{c}}$ \\
$\mathrm{R}_{5}(2 \% \mathrm{TF})$ & $152.30 \pm 22.20^{\mathrm{bc}}$ & $87.95 \pm 37.12^{\mathrm{bc}}$ & $51.30 \pm 11.68^{\mathrm{b}}$ & $68.35 \pm 7.07^{\mathrm{c}}$ \\
$\mathrm{R}_{6}($ Negative control) & $160.71 \pm 18.56^{\mathrm{c}}$ & $92.27 \pm 24.39^{\mathrm{c}}$ & $45.78 \pm 6.34^{\mathrm{ab}}$ & $67.16 \pm 6.54^{\mathrm{c}}$ \\
\hline
\end{tabular}

Description - *Superscript different within the same column shows a significant difference $(\mathrm{p}<0.01)$. **Superscript different within the same column shows a significant difference $(p<0.05)$. LDL=Low-density lipoprotein, $\mathrm{HDL}=$ High-density lipoprotein, MF=Mangosteen peel flour, TF=Turmeric flour 
$L D L$

The supplementation of MF and TF significantly affect $(p<0.05)$ LDL blood level of Cihateup ducks. The treatment of $\mathrm{R}_{2}$ containing 1.5 and $0.5 \%$ combination of mangosteen peel and TF shows the best results compared to other treatments. This result is in accordance with a previous study of Kermanshashi and Riasi [35] who report that the addition of turmeric at the level of $0.5-1.5 \mathrm{~g} / \mathrm{kg} \mathrm{BW}$ in ration can reduce LDL level, triglycerides, and total cholesterol in the blood. This is because turmeric has strong properties to change lipid profile [36]. The addition of $5 \mathrm{~g} / \mathrm{kg}$ BW of turmeric can also increase hemoglobin and red blood cells and reduce LDL and VLDL while using $2.5 \mathrm{~g} / \mathrm{kg}$ BW of feed can increase HDL level and broiler total cholesterol [25].

A higher proportion of lipids to proteins in the lipoproteins is associated with a lower density of lipoproteins. Thus, the higher the LDL levels, the lower the HDL levels. Furthermore, increases in triglyceride levels lead to increases in chylomicron and VLDL levels, as transporters of triglycerides. LDL is the last stage of VLDL catabolism; therefore, raised VLDL levels also increase LDL levels. Increased cholesterol levels result in downregulation of native LDL receptors, thus inducing LDL uptake by receptor scavengers, ultimately leading to foam cell formation [37].

$H D L$

Table-3 shows that supplementation of MF and TF significantly affect $(\mathrm{p}<0.05)$ HDL levels of Cihateup ducks $\left(\mathrm{R}_{1}, \mathrm{R}_{2}\right.$, and $\mathrm{R}_{3}$ groups). The treatment of TF only R5 shows the best results compared to controls and other treatments. This study is in accordance with that of Dono [38] who reports that the addition of turmeric at $0.35 \%$ level can increase HDL content and reduce total cholesterol, triglycerides, and LDL in broiler serum because curcumin is able to stimulate the activity of lipase-sensitive hormone. Curcumin increases lipid catabolism and reduces fat accumulation through its antioxidant. The combination of turmeric and thyme significantly $(\mathrm{p}<0.05)$ increases HDL until the $42^{\text {nd }}$ day of the study. This is because the compound of curcumin in turmeric can increase lipid catabolism and reduce fat accumulation by the presence of antioxidant properties that regulate and control the level of several hormones, inhibit the activity of several lipase enzymes, and increase the deposition of proteins in the body [6]. Adiputro et al. [33] reported that administration of the ethanolic extract of mangosteen pericarp increased HDL levels, starting at a dosage of $200 \mathrm{mg} / \mathrm{kg} \mathrm{BW}$. The main function of $\mathrm{HDL}$ is as a storage site of apolipoproteins $\mathrm{C}$ and $\mathrm{E}$, which are needed in the catabolism of chylomicrons and VLDL, where apolipoprotein $\mathrm{C}$ is a cofactor of lipoprotein lipase, and apolipoprotein $\mathrm{E}$ is a ligand for LDL receptors.
Table-4: Average abdominal fat of Cihateup ducks given ration contains mangosteen peel flour and turmeric flour of research results.

\begin{tabular}{lcc}
\hline Treatment & $\begin{array}{c}\text { Abdominal } \\
\text { fat }(\mathbf{g})\end{array}$ & $\begin{array}{c}\text { Percentage of } \\
\text { abdominal fat (\%) }\end{array}$ \\
\hline $\mathrm{R}_{0}($ Positive control) & $13.76 \pm 2.14^{\mathrm{b}}$ & $1.12 \pm 0.21^{\mathrm{b}}$ \\
$\mathrm{R}_{1}(2 \% \mathrm{MF})$ & $14.11 \pm 3.48^{\mathrm{b}}$ & $1.02 \pm 0.17^{\mathrm{b}}$ \\
$\mathrm{R}_{2}(1.5 \% \mathrm{MF} \pm 0.5 \% \mathrm{TF})$ & $12.87 \pm 3.07^{\mathrm{b}}$ & $0.86 \pm 0.22^{\mathrm{a}}$ \\
$\mathrm{R}_{3}(1 \% \mathrm{MF} \pm 1 \% \mathrm{TF})$ & $9.44 \pm 1.35^{\mathrm{a}}$ & $0.68 \pm 0.34^{\mathrm{a}}$ \\
$\mathrm{R}_{4}(0.5 \% \mathrm{MF} \pm 1.5 \% \mathrm{TF})$ & $7.33 \pm 0.89^{\mathrm{a}}$ & $0.50 \pm 0.14^{\mathrm{a}}$ \\
$\mathrm{R}_{5}(2 \% \mathrm{TF})$ & $8.44 \pm 1.22^{\mathrm{a}}$ & $0.62 \pm 0.33^{\mathrm{a}}$ \\
$\mathrm{R}_{6}($ Negative control) & $14.75 \pm 3.54^{\mathrm{b}}$ & $1.34 \pm 0.56^{\mathrm{b}}$ \\
\hline
\end{tabular}

Description - Superscript different within the same column shows a significant difference $(p<0.05), M F=$ Mangosteen peel flour, $T F=$ Turmeric flour

\section{Abdominal fat}

The data in Table- 4 show that the supplementation with MF and TF significantly reduced $(p<0.05)$ abdominal fat content $\left(\mathrm{R}_{3}, \mathrm{R}_{4}\right.$, and $\mathrm{R}_{5}$ group) in Cihateup ducks. A previous study report that the addition of $0.5 \%$ TF significantly $(\mathrm{p}<0.01)$ reduces blood fat levels $[16,39]$, abdominal fat, and liver percentages [40]. This is because curcumin has hypolipidemic and hypocholesterolemic properties that can decrease fat levels of broiler meat [41], stimulate bile secretion, and bile flow that can support liver health[38] and abdominal fat has a positive correlation with carcass weight and the percentage of abdominal fat in broilers reaches $2-3.13 \%$ at $4-8$ weeks of slaughter period [11].

The treatment added with TF (Table-4) has the best effect compared to other treatments. Bile fluid is a greenish-yellow salt containing cholesterol, phospholipid, lecithin, and bile pigment. Bile contains a number of salts resulting from the mixture of sodium and potassium with bile acids (glycolic acid and taurocholate). These salts will mix with fat in the small intestine to form micelles. If the micelle is formed, it will reduce the tension between the fat surface and the mixing motion in the digestive tract gradually can break down the fat globules into finer particles so that fat can be digested [8,9]. Frandson [42] states that bile salts which are alkaline salts can help create an alkaline atmosphere in intestinal chyme. Bile salts that neutralize the acidity of the intestinal contents in the duodenal indentation area produce an alkaline state so that it can reach the appropriate $\mathrm{pH}$, volume, and digestibility levels.

\section{Conclusion}

The supplementation of MF and TF has a good effect on the production performance, lipid profile, and abdominal fat of Cihateup ducks. Xanthone and curcumin compounds on MF and TF combined at certain levels have the best impact on almost all test parameters compared to other treatments. The combination of both at a balanced level (1\% each) is highly recommended to be applied as a supplement to poultry feed. 


\section{Authors' Contributions}

The main research work was carried out and designed by AK and CHP. The research was carried out by AK and KRB. All authors drafted and revised the manuscript, read and approved the final manuscript.

\section{Acknowledgments}

The authors would like to thank the Universitas Perjuangan and Indonesia Endowment Fund for Education (LPDP) for supporting in this study.

\section{Competing Interests} interests.

The authors declare that they have no competing

\section{Publisher's Note}

Veterinary World remains neutral with regard to jurisdictional claims in published institutional affiliation.

\section{References}

1. Wu, L., Guo, X. and Fang, Y. (2012) Effect of diet dilution ratio at early age on growth performance, carcass characteristics and hepatic lipogenesis of Pekin ducks. Braz. J. Poult. Sci., 14(1): 43-49.

2. Ismoyowati, I. and Sumarmono, J. (2011) Fat and cholesterol contents of local duck (Anas platyrhynchos platyrhynchos) meat fed mash, paste and crumble feeds. Asian J. Poult. Sci., 5(4): 150-154.

3. Nisha, A.R. (2008) Antibiotic residues a global health hazard (review). Vet. World, 1(12): 375-377.

4. Christaki, E., Bonos, E., Giannenas, I. and Florou-Paneri, P. (2012) Aromatic plants as a source of bioactive compounds. Agriculture, 2(4): 228-243.

5. Chaiwat, S. (2003) Effect of turmeric (Curcuma longa Linn.) as an antioxidant on immune status and growth performances of stressed broilers. Thesis. Chulalongkorn University, Bangkok. Thailand.

6. Fallah, R. and Mirzaei, E. (2016) Effect of dietary inclusion of turmeric and thyme powders on performance, blood parameters and immune system of broiler chickens. Livest. Sci., 7(1): 180-186.

7. Zuprizal, Z., Yuwanta, T., Supadmo, Y., Kusmayadi, A., Wati, A.K., Martien, R. and Sundari, S. (2015) Effect of liquid nanocapsule level on broiler performance and total cholesterol. Int. J. Poult. Sci., 14(7): 403-406.

8. Darwis, S.N., Modjo, I.A.B. and dan Hasiyah, S. (1991) Medicinal Plants Family Zingiberaceae. Industrial Agriculture Research and Development Agency, Bogor, Indonesia.

9. Pratikno, H. (2010) Effect of turmeric extract (Curcuma domestica Vahl) on broiler chicken body weight (Gallus sp). Bul. Anat. Fisiol., 18(2): 39-46.

10. Adnyana, I.K., Abuzaid, A.S., Iskandar, E.Y. and Kurniati, N.F. (2016) Pancreatic lipase and $\alpha$-amylase inhibitory potential of mangosteen (Garcinia mangostana Linn.) pericarp extract. Int. J. Med. Res. Health Sci., 5(1): 23-28.

11. Hidanah, S., Warsito, S.H., Nurhajati, T., Lokapirnasari, W.P. and Malik,A.(2017)Effects ofmangosteen peel(Garciniamangostana) and ginger rhizome (Curcuma xanthorrhiza) on the performance and cholesterol levels of heat-stressed broiler chickens. Pak. J. Nutr., 16(1): 28-32.

12. Choubey, S. (2018) Extraction and evaluation of anti-oxidants from different fruit peels : A review. World. J. Pharm. Res., 7(3): 363-376.

13. Ürüşan, H. and Bölükbaşı, Ş.C. (2017) Effects of dietary supplementation levels of turmeric powder(Curcuma longa) on performance, carcass characteristics and gut microflora in broiler chickens. J. Anim. Plant Sci., 27(3): 732-736.

14. Palapol, Y., Ketsa, S., Stevenson, D., Cooney, J.M., Allan, A.C. and Ferguson, I.B. (2009) Colour development and quality of mangosteen (Garcinia mangostana L.) fruit during ripening and after harvest. Postharvest Biol. Technol., 51(3): 349-353.

15. Erhan, M.K., Bölükbaşi, Ş.C. and Ürüşan, H. (2012) Biological activities of pennyroyal (Mentha pulegium L.) in broilers. Livest. Sci., 146(2): 189-192.

16. Mondal, M., Yeasmin, T., Karim, R., Siddiqui, M.N., Nabi, S.R., Sayed, M. and Siddiky, M. (2015) Effect of dietary supplementation of turmeric (Curcuma longa) powder on the growth performance and carcass traits of broiler chicks. SAARC J. Agri., 13(1): 188-199.

17. Craig, W.J. (1999) Health-promoting properties of common herbs. Am. J. Clin. Nutr., 70(3): 491-499.

18. Namagirilakshmi, S., Selvaraj, P., Nanjappan, K., Jayachandran, S. and Visha, P. (2010) Turmeric (Curcuma longa) as an alternative to in-feed antibiotic on the gut health of broiler chickens. Tamil Nadu J. Vet. Anim. Sci., 6(3): 148-150.

19. Ratika, K., Singh, R.K.J., Singh, R.K. and Singh, M. (2018) Weekly assessment of growth performance of broilers fed diet supplemented with garlic and turmeric powder and their combination. Int. J. Curr. Microbiol. Appl. Sci., 7(2): 1373-1381.

20. Földešiová, M., Baláži, A., Chrastinová, L. and Chrenek, P. (2015) The effect of Curcuma longa dried powder in the diet on weight gain of rabbit does. Slovak. J. Anim. Sci., 48(1): 43-48.

21. Samarasinghe, K., Wenk, C., Silva, K.F.S. and Gunasekera, J.M.D. (2003) Turmeric (Curcuma longa) root powder and mannanoligosaccharides as alternatives to antibiotics in broiler chicken diets. Asian-Australas. J. Anim. Sci., 16(10): 1495-1500.

22. Attia, F.A. (2018) The influence of supplementing chamomile and turmeric powder on productive performance and egg quality of laying hens. Egypt. Poult. Sci., 5623(38): 451-463.

23. Setiawan, D.V., Djunaidi, I.H. and Sudjarwo, E. (2013) Effect of addition mangosteen peel powder (Garcinia mangostana L.) as feed additive to the production performance of male Mojosari duck. J. Brawijaya, 5(1): 1-6.

24. Toghyani, M., Toghyani, M., Gheisari, A., Ghalamkari, G. and Mohammadrezaei, M. (2010) Growth performance, serum biochemistry and blood hematology of broiler chicks fed different levels of black seed (Nigella sativa) and peppermint (Mentha piperita). Livest. Sci., 129(1): 173-178.

25. Emadi, M. and Kermanshahi, H. (2007) Effect of turmeric rhizome powder on the activity of some blood enzymes in broiler chickens. Int. J. Poult. Sci., 6(1): 48-51.

26. Durrani, F.R., Ismail, M., Sultan, A., Suhail, S.M., Chand, N. and Durrani, Z. (2006) Effect of different levels of feed added turmeric (Curcuma longa) on the performance of broiler chicks. J. Agric. Biol. Sci., 1(2): 9-11.

27. Ismoyowati, I., Indrasanti, D., Mufti, M. and Farjam, A.S. (2015) Phytobiotic properties of garlic, red ginger, turmeric and kencur in growing ducks. J. Anim. Prod., 17(1): 49-55.

28. Shivappa, N.H.B., Umakantha, B., Wilfred, R.S., Murthy, H.N.N. and Narayanaswamy, H.D. (2013) Performance and hematological parameters of broilers fed neem, turmeric, Vitamin E and their combinations. Emirates J. Food Agric., 25(6): 483-488.

29. Lokesh, G., Ananthanarayana, S.R. and Yogananda, M.V.N. (2012) Changes in the activity of digestive enzymes in response to chemical mutagen diethyl sulfate in the silkworm Bombyx mori L. (Lepidoptera: Bombycidae). Asian J. Appl. Sci., 5(6): 431-437.

30. Ahmadi, F. (2010) Effect of turmeric (Curcuma longa) powder on performance, oxidative stress state and some of 
blood parameters in broiler fed on diets containing aflatoxin B1. Glob. Vet., 5(6): 312-317.

31. Qasem, M.A.A.,Alhajj, M.S. and Nabi,A.R.J. (2016) Effects of dietary supplement of turmeric powder (Curcuma longa) on blood biochemistry parameters and antioxidant activity in chickens. S. Afr. J. Anim. Sci., 46(2): 204-213.

32. Chen, J. and Huang, X.F. (2009) The effects of diets enriched in beta-glucans on blood lipoprotein concentrations. J. Clin. Lipidol., 3(3): 154-158.

33. Adiputro, D.L., Widodo, M.A., Romdoni, R. and Sargowo. D. (2013) Extract of mangosteen increases high-density lipoprotein levels in rats fed high lipid. J. Univ. Med., 32(1): 37-43.

34. Chomnawang, M.T., Surassmo, S., Nukoolkarn, V.S. and Gritsanapan, W. (2007) Effect of Garcinia mangostana on inflammation caused by Propionibacterium acnes. Fitoterapia, 78(6): 401-408.

35. Kermanshashi, H. and Riasi, A. (2006) Effect of turmeric rhizome powder (Curcuma longa) and soluble NSP degrading enzyme on some blood parameters of laying hens. Int J. Poult. Sci., 5(5): 494-498.

36. Riasi, A., Kermanshahi, H. and Mahdavi, A.H. (2012) Production performance, egg quality and some serum metabolites of older commercial laying hens fed different levels of turmeric rhizome (Curcuma longa) powder. $J$. Med. Plant Res., 6(11): 2141-2145.

37. McLaren, J.E., Michael, D.R., Ashlin, T.G. and Ramji, D.P. (2011) Cytokines, macrophage lipid metabolism and foam cells: Implications for cardiovascular disease therapy. Prog. Lipid Res., 50(4): 331-347.

38. Dono, N.D. (2013) Turmeric (Curcuma longa Linn.) supplementation as an alternative to antibiotics in poultry diets. Wartazoa, 23(1): 41-49.

39. Al-Sultan, S.I. (2003) The effect of Curcuma longa (Tumeric) on overall performance of broiler chickens. Int. J. Poult. Sci., 2(5): 351-353.

40. Attia, Y.A., Al-Harthi, M.A. and Hassan, S.S. (2017) Turmeric (Curcuma longa Linn.) as a phytogenic growth promoter alternative for antibiotic and comparable to mannan oligosaccharides for broiler chicks. Rev. Mex. Cien. Pecuarias, 8(1): 11-21.

41. Hidayat, M., Zuprizal, Z., Sundari, S., Kurniawati, A. and Kusmayadi, A. (2017) The effect of liquid tumeric extract supplementation on carcass production and chemical quality of broiler meat. J. Indones. Trop. Anim. Agric., 42(1): 6-13.

42. Frandson, R.D. (1992) Anatomy and Physiology. Interpreting Bambang Srigandono and Koen Praseno. $4^{\text {th }}$ ed. Gadjah Mada University Press, Yogyakarta. 